\title{
Relation of maternal and cord blood serum ferritin
}

\author{
M. A. M. HUSSAIN, T. H. GAAFAR, MARTINE LAUliCHT, AND A. V. HOFFBRAND \\ From the Department of Haematology, Royal Free Hospital, London, and Hull Maternity Hospital, Hull
}

SUMMARY Serum ferritin was measured in 51 term normal pregnant mothers and the corresponding cord blood samples. All of the mothers had received prophylactic oral iron and folate during pregnancy. The mean $( \pm \mathrm{SD})$ maternal serum ferritin at the end of pregnancy was $58 \pm 42 \cdot 9 \mu \mathrm{g} / \mathrm{l}$ (range 16-201 $\mu \mathrm{g} / \mathrm{l}$ ), compared to a mean of $183 \cdot 2 \pm 61 \cdot 2 \mu \mathrm{g} / \mathrm{l}$ (range 62-313 $\mu \mathrm{g} / \mathrm{l}$ ) in these newborns. No correlation was found between the serum ferritin of mothers and babies, nor between the serum ferritin and serum iron of mothers at the end of pregnancy or between these parameters in the newborn.

The iron content of the newborn infant is an important source of iron for haemoglobin formation in the first few months of life since the iron content of milk is low. Until recently it has been difficult to assess the influence of maternal iron stores on the iron status of the newborn infant. The introduction of the serum ferritin assay (Addison et al., 1972) has provided a simple, sensitive guide of body iron stores. The purpose of the present study was to determine the relation of serum ferritin of mothers at the time of delivery, and the corresponding cord blood.

\section{Patients and methods}

Fifty-one pregnant women (age range 17-38 years; each had 1-6 pregnancies) attending the Obstetric Clinic at Hull Maternity Hospital contributed in this study. All of them had a term normal pregnancy and normal delivery. Their babies were all term and of normal weight. All of the mothers had received one tablet of Ferrograd-folic per day (ferrous sulphate BP $325 \mathrm{mg}$ and $350 \mu \mathrm{g}$ folic acid BP) since early pregnancy.

When the mothers were admitted for delivery, blood samples were obtained from them for determination of $\mathrm{Hb}$, serum iron, total iron binding capacity (TIBC), and serum ferritin. Similar tests were done on cord blood samples.

The method used for serum iron and TIBC was that recommended by the International Committee for Standardization in Hematology (1971). Normal range for serum iron is $75-130 \mu \mathrm{g} / 100 \mathrm{ml}(13 \cdot 4$ $23 \cdot 3 \mu \mathrm{mol} / \mathrm{l})$, and for TIBC $270-390 \mu \mathrm{g} / 100 \mathrm{ml}$

Received 4 March 1977
(48.3-70 $\mu \mathrm{mol} / \mathrm{l})$. Serum ferritin was measured by the method of Addison et al. (1972), and $\mathrm{Hb}$ by a Coulter $\mathbf{S}$ counter.

\section{Results}

$\mathrm{Hb}$, serum ferritin, serum iron, and TIBC of the mothers and newborn babies (cord blood samples) are shown in the Table. 4 of the mothers were anaemic $(\mathrm{Hb}<11 \cdot 5 \mathrm{~g} / \mathrm{dl}) .3$ of these 4 had low serum iron levels and all 4 had low serum ferritin values. None of the maternal samples showed a serum ferritin in the range found in iron deficiency anaemia $(0-12 \mu \mathrm{g} / \mathrm{l})$. The cord $\mathrm{Hb}$ was normal in all babies (mean cord $\mathrm{Hb}$ for mature neonates is $17 \mathrm{~g} / \mathrm{dl}$ with a range of 13.3-20.8 g/dl (Burman, 1959). The mean serum iron of the newborn babies and their mean TIBC were both increased. The mean TIBC of the mothers was also greatly increased compared to normal adult levels in nonpregnant women.

The mean $( \pm \mathrm{SD})$ maternal serum ferritin was $58 \pm 42.9 \mu \mathrm{g} / 1$ (range 16-201 $\mu \mathrm{g} / \mathrm{l})$. The mean value for the newborns was $183 \cdot 2 \pm 61 \cdot 2 \mu \mathrm{g} / \mathrm{l}$ (range 62$313 \mu \mathrm{g} / \mathrm{l})$. There was no correlation between maternal and cord blood serum ferritin $(r=0 \cdot 3)$ (Fig.). There was also no correlation between maternal serum ferritin and maternal serum iron or per cent saturation of the iron binding capacity or between cord blood serum ferritin and cord serum iron or per cent saturation of the iron binding capacity.

\section{Discussion}

From conception until birth a normal fetus acquires 250-300 mg iron (Burman, 1974). During pregnancy the only source of fetal iron appears to be maternal 


\begin{tabular}{lll}
\hline Parameter & Mean (range) for mothers & $\begin{array}{c}\text { Mean }(\text { range }) \text { of newborn babies } \\
\text { (cord blood })\end{array}$ \\
\hline Haemoglobin $(\mathrm{g} / \mathrm{dl})$ & $12 \cdot 9(9 \cdot 6-15 \cdot 6)$ & $17 \cdot 0(14 \cdot 6-21 \cdot 3)$ \\
Serum iron $(\mu \mathrm{g} / 100 \mathrm{ml})$ & $125(45-220)$ & $191(90-480)$ \\
TIBC $(\mu \mathrm{g} / 100 \mathrm{ml})$ & $607(375-900)$ & $339(120-540)$ \\
Serum ferritin $(\mu \mathrm{g} / \mathrm{l})$ & $58(16-210)$ & $183(62-313)$ \\
\hline
\end{tabular}

Conversion: Traditional units to SI-Serum iron and TIBC: $1 \mu \mathrm{g} / 100 \mathrm{ml} \approx 0 \cdot 179 \mu \mathrm{mol} / 1$.

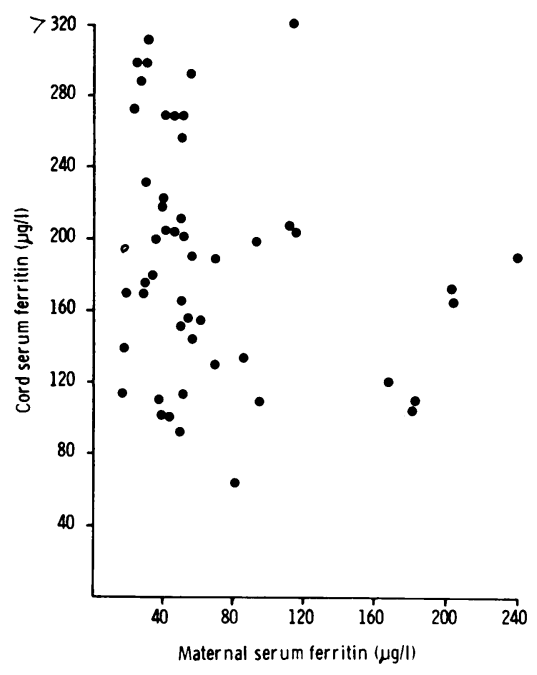

Fig. Relation of maternal to fetal (cord blood) serum ferritin.

plasma iron and so pregnant women are likely to become iron deficient if this fetal requirement is not allowed for. Earlier studies on iron status during pregnancy suggested that children born to severely iron-deficient mothers develop iron deficiency anaemia themselves later on in infancy, and this might be due to depleted iron stores at birth (Strauss, 1933). Subsequently, several studies on humans and experimental animals disproved this idea and showed that in iron-deficient pregnant mothers total fetal iron was not reduced, though proportionately more of the fetal iron came from maternal iron absorption than from maternal iron stores (Fullerton, 1937; Sturgeon, 1959; Lanzkowsky, 1961; Beischer et al., 1970; Murray and Stein, 1971). These previous studies comparing iron status of pregnant mothers and their newborn babies were based on the standard tests of serum iron, TIBC, and percentage saturation.

Serum ferritin is a good measure of the iron storage of the body, particularly of iron in the reticuloendothelial system, but so far little work has been reported on late pregnancy and on cord blood. A recent study on 20 normal and 6 iron-deficient mothers showed no relationship between the predelivery serum ferritin in the two populations of mothers and the serum ferritin of their newborns' cord blood (Rios et al., 1975). Our group of mothers who had received oral iron since early pregnancy and showed higher values than those of Rios et al. for both predelivery and cord serum ferritin, also did not show any correlation between maternal and cord serum ferritin. On the other hand, Cavill et al. (1977) found lower serum ferritin concentrations in cord blood samples of iron-deficient mothers than of ironreplete mothers. The explanation for the difference between their findings and those of the present series is uncertain but may be that serum ferritin and presumably iron stores are only reduced in neonates if maternal iron stores are completely exhausted, and that was not the case in any of our subjects. Maternal serum ferritin levels at term in the present study closely correlated with those of nonpregnant female controls (mean serum ferritin $55.9 \mu \mathrm{g} / \mathrm{l}$, Hussein et al., 1976).

Previous experimental work has shown that transfer of iron across the placenta occurs against a concentration gradient for plasma iron and transferrin saturation (Fletcher and Suter, 1969), but despite substantial research on the placental transfer of iron the mechanism by which the placenta acts as a regulator of iron transfer from maternal to fetal transferrin remains obscure. Experimental animal studies have shown that the fetus does not show excessive tissue accumulation of iron even after very high doses of parenteral iron have been given to pregnant mothers. It will be of interest, therefore, to study cord blood ferritin from pregnant patients with iron overload as well as from those with iron deficiency.

M.A.M.H., from the Department of Child Health, Faculty of Medicine, Khartoum, is in receipt of a scholarship from the Sudanese Government. We also thank the consultant obstetricians at Hull Maternity Hospital for permission to investigate women under their care. 


\section{References}

Addison, G. M., Beamish, M. R., Hales, C. N., Hodgkins, M., Jacobs, A., and Llewellin, P. (1972). An immunoradiometric assay for ferritin in serum of normal subjects and patients with iron deficiency and iron overload. Journal of Clinical Pathology, 25, 326-329.

Beischer, N. A., Sivasamboo, R., Vohra, S., Silpisornkosal, S., and Reid, S. (1970). Placental hypertrophy in severe pregnancy anaemia. Journal of Obstetrics and Gynaecology of the British Commonwealth, 77, 398-409.

Burman, D. (1959). The normal cord haemoglobin level. Journal of Obstetrics and Gynaecology of the British Empire, 66, 147-150.

Burman, D. (1974). Iron metabolism in infancy and childhood. Iron in Biochemistry and Medicine, p. 543. Ed. by A. Jacobs and M. Worwood. Academic Press, London and New York.

Cavill, I., Fenton, V., and Fisher, J. (1977). Iron stores in pregnancy. British Journal of Haematology (in press).

Fletcher, J., and Sutter, P. E. N. (1969). The transport of iron by the human placenta. Clinical Science, 36, 209-220.

Fullerton, H. W. (1937). The iron-deficiency anaemia of late infancy. Archives of Disease in Childhood, 12, 91-110.

Hussein, S., Hoffbrand, A. V., Laulicht, M., Attock, B., and Letsky, E. (1976). Serum ferritin levels in beta-thalassaemia trait. British Medical Journal, 2, 920.
International Committee for Standardization in Hematology (1971). Proposed recommendations for measurement of serum iron in human blood. British Journal of Haematology, 20, 451-456.

Lanzkowsky, P. (1961). The influence of maternal irondeficiency anaemia on haemoglobin of the infant. Archives of Disease in Childhood, 36, 205-209.

Murray, M. J., and Stein, N. (1971). Contribution of maternal rat iron stores to fetal iron in maternal iron deficiency and overload. Journal of Nutrition, 101, 15831588.

Rios, E., Lipschitz, D. A., Cook, J. D., and Smith, N. J. (1975). Relationship of maternal and infant iron stores as assessed by determination of plasma ferritin. Pediatrics, 55, 694-699.

Strauss, M. B. (1933). Anemia of infancy from maternal iron deficiency in pregnancy. Journal of Clinical Investigation, 12, 345-353.

Sturgeon, P. (1959). Studies of iron requirements in infants. III. Influence of supplemental iron during normal pregnancy on mother and infant. British Journal of Haematology, 5, 31-44.

Correspondence to Prof. A. V. Hoffbrand, Department of Haematology, The Royal Free Hospital, Pond Street, Hampstead, London NW3 2QG. 